\title{
The Role of Anti-Nerve Growth Factor Monoclonal Antibodies in the Control of Chronic Cancer and Non-Cancer Pain
}

\author{
Sabrina Bimonte (1D* \\ Marco Cascella (iD* \\ Cira Antonietta Forte (D) \\ Gennaro Esposito (D) \\ Arturo Cuomo (D)
}

Division of Anesthesia and Pain Medicine, Istituto Nazionale dei Tumori, IRCCS Fondazione G. Pascale, Naples, Italy

*These authors contributed equally to this work
Correspondence: Sabrina Bimonte Division of Anesthesia and Pain Medicine, Istituto Nazionale dei Tumori, IRCCS Fondazione G. Pascale, Napoli, Italy Email s.bimonte@istitutotumori.na.it

\begin{abstract}
Nerve growth factor (NGF) belongs to the neurotrophin family and plays a fundamental role in the endurance of sensory and sympathetic neurons during embryogenesis. NGF, by interacting with tropomyosin receptor kinase A receptor (TrkA), modulates the pain pathway through the enhancement of the neurotrophic and nociceptor functions. Moreover, it has been demonstrated that NGF is upregulated in patients with chronic pain syndromes, which are difficult to treat. Thus, new non-pharmacological approaches, based on the use of different species-specific monoclonal antibodies (mAbs) targeting the NGF pathway, have been tested for the treatment of chronic pain in preclinical and clinical studies. With regard to preclinical investigations, anti-NGF mAbs have been used for the management of osteoarthritis (OA) and chronic low back pain animal models, with encouraging results. Moreover, anti-NGF $\mathrm{mAb}$ therapy is effective in animal models of neuropathic cancer pain. As regards patients with OA, although phase II and phase III clinical trials with tanezumab led to pain reduction, the safety was not observed in all these patients. Here, we review the preclinical and clinical studies on anti-NGF mAb therapy in chronic syndromes, dissect the role of NGF in pain transduction, and highlight the use of anti-NGF mAbs in humans.
\end{abstract}

Keywords: nerve growth factor, monoclonal antibodies, peripheral sensitization, chronic pain, neuropathic cancer pain

\section{Introduction}

Nerve growth factor (NGF), discovered by Rita Levi-Montalcini in 1952, belongs to the neurotrophin family, along with as neurotrophin-3 (NT-3), neurotrophin-4 (NT-4), and brain-derived growth factor (BDNF). It plays an important role in neuronal survival during the course of embryogenesis. ${ }^{1,2}$ During development, NGF and other neurotrophins bind to a member of the tropomyosin-related kinase (Trk) receptor family and the low-affinity p75 neurotrophin receptor (NTR) on the neuronal cell surface, then activate different signaling pathways involved in neuronal growth and survival and thus modulate pain pathogenesis. ${ }^{3-5}$ Moreover, in adults, NGF influences the nociceptive neuronal activity. ${ }^{6}$

Preclinical and clinical studies have clearly highlighted the important role of NGF in acute and chronic pain modulation. In particular, chronic pain is an extremely heterogeneous source of suffering and derives from different pathological conditions, such as osteoarthritis (OA), chronic low back pain (CLBP), cancer, and other forms of disease. ${ }^{7}$ Current therapies for the treatment of chronic 
pain are essentially based on pharmacological approaches (ie opiates, non-steroidal anti-inflammatory drugs [NSAIDs], and other drugs), which often lead to longterm side effects. ${ }^{8,9}$ Since NGF has been identified as an important mediator of chronic pain syndromes, new strategies of treatment based on NGF blockade or anti-NGF antibodies have been demonstrated in both preclinical and clinical trials. ${ }^{10}$ Many humanized anti-NGF monoclonal antibodies (mAbs) have been tested in clinical trials as potential pain therapies (ie tanezumab, fulranumab, and fasinumab); in particular, tanezumab was used in phase III trials in OA, although the safety of these patients was not uniformly reached. ${ }^{11}$ With regard to preclinical investigations, anti-NGF mAbs have been engineered and tested for the management of OA animal models, with encouraging results. ${ }^{10-13}$ Moreover, several studies have highlighted the effect of anti-NGF antibodies in different animal models of neuropathic pain. ${ }^{14-16}$ Thus, new therapies based on the use of different mAbs targeting the NGF pathway have been tested for chronic pain treatment in preclinical and clinical studies.

Here, we review the preclinical and clinical studies on anti-NGF mAb therapy in chronic syndromes, the role of NGF in pain transduction, and the need for anti-NGF mAbs in humans. Studies cited in this narrative review were discovered through PubMed searches. PubMed was searched for both preclinical and clinical articles related to "NGF and chronic pain" and "NGF and cancer pain".

\section{NGF and Pain-Related Mechanisms}

NGF plays an important role in the generation and maintenance of both nociceptive and neuropathic pain by regulating a complex signaling pathway. In briefly (see Kumar and $\mathrm{Mahal}^{17}$ for more details), NGF interacts with the high-affinity TrkA and lowers the neurotrophic receptor p75 (NTR) receptors. Cell survival and neurite outgrowth are reached through the activation of TrkAmediated Ras (Rat sarcoma) and PI3 kinase (PI3K) pathways. The TrkA-activated PI3K pathway blocks the signaling through p75NTR, which leads to apoptosis. Moreover, the activation of PI3K signaling promotes the phosphorylation of the non-selective cation channel transient receptor potential cation channel subfamily $\mathrm{V}$ member 1 (TRPV1), resulting in the enhancement of nociceptive function.

NGF can modulate nociception by releasing inflammatory mediators, by regulating the activity of the nociceptive ion channel/receptor and the expression of the nociceptive gene, and by the sprouting of local neurons in complex machinery involved in its downstream signaling pathways. ${ }^{17,18}$

\section{In Vivo Preclinical Studies on the Effects of Anti-NGF mAbs in Animal Models of Chronic Pain: An Update}

Since NGF can modulate pain in chronic conditions, new therapeutic approaches, based on the use of different neutralizing or antibodies targeting its pathway, have been developed and tested in animal models of chronic pain (Table 1). ${ }^{19-30}$ In particular, anti-NGF mAbs have been engineered and tested for the management of osteoarthritis (OA), a progressive degenerative joint disease. Importantly, the earlier published studies, only detected the effects of NGF blockade on pain behavior, whereas more recent studies also assessed the effects on pathological joints. These studies also highlighted some adverse effects linked to anti-NGF treatment, including cartilage damage, tibial osteophytes, and subchondral bone sclerosis. ${ }^{10}$

The first report on the effects of NGF blockade (using a neutralizing antibody against NGF) in an animal model of OA was published by McNamee et al. ${ }^{19}$ In this study, the authors used a mouse model of destabilization of the medial meniscus (DMM) of OA to test the effects of NGF and its soluble receptor, TrkAD5, in pain assessment. Their data demonstrated that TrkAD5 suppressed the pain in OA mice. Similar findings were presented by Flannery et al in a rat mono-iodoacetate (MIA) model. ${ }^{20}$ Bryden et al demonstrated that a subcutaneous injection of anti-NGF $\mathrm{mAb}$, in a rat MIA model, reversed deficits in burrowing compared to non-treated mice. ${ }^{21}$ To date, few preclinical studies conducted on animal models of chronic pain have assessed both pain and joint changes after antiNGF mAb treatment. Ishikawa et al demonstrated that a single dose of an anti-NGF antibody had a long-lasting analgesic effect on pain during motion, lesion, and joint edema in a rat model of OA. ${ }^{22}$ In the same year (2015), a research group proved, for the first time, the efficacy of a canine-specific anti-NGF $\mathrm{mAb}$ in a dog with degenerative joint disease. ${ }^{23}$

Another study based on pain assessment was performed by $\mathrm{Kc}$ et al, which assessed the effect of multiple intra-articular administrations of an anti-NGF mAb into the knee of protein kinase $\mathrm{C} \delta(\mathrm{PKC} \delta)$ null mice subjected to DMM surgery. ${ }^{24}$ Informative data on the 
Table I Summary of In Vivo Studies on the Role of Anti-NGF in Animal Models of Chronic Pain

\begin{tabular}{|c|c|c|c|c|c|}
\hline $\begin{array}{l}\text { Type of } \\
\text { Study }\end{array}$ & Model & $\begin{array}{l}\text { Type of } \\
\text { Blocker }\end{array}$ & Dose & Effects and Adverse Effects & Reference \\
\hline $\begin{array}{l}\text { Pain } \\
\text { assessment }\end{array}$ & $\begin{array}{l}\text { Mouse model of } \\
\text { DMM }\end{array}$ & TrkAd5 & $\begin{array}{l}2 \mathrm{mg} / \mathrm{kg} \text { either the day before } \\
\text { surgery or } 16 \text { weeks after } \\
\text { surgery (s.c.) }\end{array}$ & $\begin{array}{l}\text { Reversion of the weight-bearing after } \\
\text { treatment with TrkAd5 at } 3 \text { days and } 16 \\
\text { weeks after surgery. Adverse effects were } \\
\text { not evaluated }\end{array}$ & $\begin{array}{l}\text { McNamee } \\
2010^{19}\end{array}$ \\
\hline $\begin{array}{l}\text { Pain } \\
\text { assessment }\end{array}$ & Rat model of MIA & $\begin{array}{l}\text { Small molecule } \\
\text { inhibitor of } \\
\text { TrkA }\end{array}$ & $\begin{array}{l}\text { Injection on day } 7 \text { after MIA } \\
\text { induction (i.a.) }\end{array}$ & $\begin{array}{l}\text { Reversion of the weight-bearing asymmetry } \\
\text { of rats with MIA after } 7 \text { days from TrkAd5 } \\
\text { inhibitor treatment. Adverse effects were } \\
\text { not evaluated }\end{array}$ & $\begin{array}{l}\text { Flannery } \\
2015^{20}\end{array}$ \\
\hline $\begin{array}{l}\text { Pain } \\
\text { assessment }\end{array}$ & Rat model of MIA & $\begin{array}{l}\text { Anti-NGF } \\
\mathrm{mAb}\end{array}$ & $\begin{array}{l}9 \mathrm{mg} / \mathrm{kg}, 2 \text { days after MIA } \\
\text { induction (s.c.) }\end{array}$ & $\begin{array}{l}\text { Reversion of the rat MIA model burrowing } \\
\text { deficit after } 3 \text { days from mAb treatment. } \\
\text { Adverse effects were not evaluated }\end{array}$ & $\begin{array}{l}\text { Bryden } \\
2015^{21}\end{array}$ \\
\hline $\begin{array}{l}\text { Pain and } \\
\text { joint } \\
\text { assessment }\end{array}$ & Rat model of OA & $\begin{array}{l}\text { Anti-NGF } \\
\mathrm{mAb} \\
\text { AS288640I-00 }\end{array}$ & 0.3 or $1 \mathrm{mg} / \mathrm{kg}$ on day 3 (i.v.) & $\begin{array}{l}\text { Anti-NGF mAb exerted a long-lasting } \\
\text { analgesic effect on pain during motion in } \\
\text { a rat model of OA. AS288640 I- } 00 \text { did not } \\
\text { suppress either edema or lesion of joint }\end{array}$ & $\begin{array}{l}\text { Ishikawa } \\
2015^{22}\end{array}$ \\
\hline $\begin{array}{l}\text { Veterinary } \\
\text { pilot study }\end{array}$ & $\begin{array}{l}\text { Dogs with } \\
\text { degenerative } \\
\text { joint disease }\end{array}$ & $\begin{array}{l}\text { Canine-specific } \\
\text { anti-NGF mAb }\end{array}$ & $\begin{array}{l}\text { Single dose of } 200 \mu g / \mathrm{kg} \text { of } \\
\text { a } 2 \mathrm{mg} / \mathrm{mL} \text { solution (i.v.) }\end{array}$ & $\begin{array}{l}\text { Alleviation of pain and mobility } \\
\text { improvement in treated dogs with } \\
\text { degenerative joint disease. Adverse effects } \\
\text { were not evaluated }\end{array}$ & $\begin{array}{l}\text { Lascelles } \\
2015^{23}\end{array}$ \\
\hline $\begin{array}{l}\text { Pain } \\
\text { behavior }\end{array}$ & $\begin{array}{l}\text { PKC } \delta \text { null mice } \\
\text { subjected to } \\
\text { DMM surgery }\end{array}$ & $\begin{array}{l}\text { Anti-NGF } \\
\mathrm{mAb}\end{array}$ & $\begin{array}{l}30 \mu g \text { (i.a.) given twice weekly } \\
\text { from week } 2 \text { to week } 8 \text { post- } \\
\text { DMM surgery }\end{array}$ & $\begin{array}{l}\text { Treatment reduced mechanical allodynia of } \\
\text { the hind paw from week } 3 \text { to week } 8 \text {. } \\
\text { Adverse effects were not evaluated }\end{array}$ & Kc $2016^{24}$ \\
\hline $\begin{array}{l}\text { Pain and } \\
\text { joint } \\
\text { assessment }\end{array}$ & $\begin{array}{l}\text { Rat MIA or rat } \\
\text { MNX model }\end{array}$ & $\begin{array}{l}\text { Active } \\
\text { inhibitor of } \\
\text { TrkA kinase } \\
\text { activity }\end{array}$ & 30 mg/kg (o.g.) & $\begin{array}{l}\text { In the MIA model, treatment provoked } \\
\text { a significant reduction in histological } \\
\text { synovitis score and a trend toward } \\
\text { a decrease in macroscopic chondropathy, } \\
\text { histological cartilage degeneration, and } \\
\text { subchondral bone scores by day } 2 \mathrm{I} \text {. } \\
\text { In the MNX model, treatment caused no } \\
\text { effect on macroscopic chondropathy or } \\
\text { histological cartilage degeneration scores, } \\
\text { but a trend toward decreased knee swelling } \\
\text { and increased histological subchondral } \\
\text { bone score by day } 2\end{array}$ & $\begin{array}{l}\text { Nwosu } \\
2016^{25}\end{array}$ \\
\hline $\begin{array}{l}\text { Pain and } \\
\text { joint } \\
\text { assessment }\end{array}$ & Rat model (MMT) & $\begin{array}{l}\text { Humanized } \\
\text { anti-NGF mAb } \\
\text { (tanezumab) }\end{array}$ & $\begin{array}{l}\text { Preventive }(0.1, \mathrm{I} \text {, or } 10 \mathrm{mg} / \mathrm{kg} \text {, } \\
\text { s.c., weekly from day of surgery } \\
\text { through day } 28 \text { after surgery) }\end{array}$ & $\begin{array}{l}\text { Tanezumab treatment led to increased } \\
\text { tibial cartilage degeneration at days } 7,14, \\
\text { and } 28 \text {. Increased tibial osteophytes by day } \\
28 \text { for all doses }\end{array}$ & $\begin{array}{l}\text { LaBranche } \\
2017^{26}\end{array}$ \\
\hline $\begin{array}{l}\text { Pain and } \\
\text { joint } \\
\text { assessment }\end{array}$ & Rat model of MIA & $\begin{array}{l}\text { Anti-NGF } \\
\text { mAb muMab } \\
\text { 91। }\end{array}$ & $\begin{array}{l}10 \mathrm{mg} / \mathrm{kg} \text { (s.c.), weekly from } \\
\text { the day of MIA induction }\end{array}$ & $\begin{array}{l}\text { Anti-NGF mAb treatment attenuated OA } \\
\text { pain behavior. Increased cartilage damage, } \\
\text { subchondral bone sclerosis, and tibial } \\
\text { osteophytes were detected in treated mice }\end{array}$ & $\mathrm{Xu} 2016^{27}$ \\
\hline
\end{tabular}

(Continued) 
Table I (Continued).

\begin{tabular}{|c|c|c|c|c|c|}
\hline $\begin{array}{l}\text { Type of } \\
\text { Study }\end{array}$ & Model & $\begin{array}{l}\text { Type of } \\
\text { Blocker }\end{array}$ & Dose & Effects and Adverse Effects & Reference \\
\hline $\begin{array}{l}\text { Pain and } \\
\text { joint } \\
\text { assessment }\end{array}$ & $\begin{array}{l}\mathrm{C} 3 \mathrm{H} / \mathrm{HeJ} \text { mouse } \\
\text { model of }\end{array}$ & $\begin{array}{l}\text { Anti-NGF } \\
\mathrm{mAb} \\
(\mathrm{mAb} / \mathrm{II}) \text { at } \\
\text { a dose of } \\
10 \mathrm{mg} / \mathrm{kg}\end{array}$ & 10 mg/kg (i.p.) & $\begin{array}{l}\text { Treatment with anti-NGF mAb increased } \\
\text { spontaneous day/night activity and rearing } \\
\text { in mice with acute post-orthopedic surgery } \\
\text { pain }\end{array}$ & $\begin{array}{l}\text { Majuta } \\
2017^{28}\end{array}$ \\
\hline $\begin{array}{l}\text { Pain and } \\
\text { joint } \\
\text { assessment }\end{array}$ & $\begin{array}{l}\text { C57BR/J mouse } \\
\text { model of MIA }\end{array}$ & $\begin{array}{l}\text { Anti-NGF } \\
\mathrm{mAb}\end{array}$ & 10 mg/kg (i.p.) & $\begin{array}{l}\text { Anti-NGF mAb suppressed the impairment } \\
\text { of gait and upregulated CGRP in DRG } \\
\text { neurons. These finding suggest that anti- } \\
\text { NGF therapy might be valuable in the } \\
\text { treatment of OA pain in the knee }\end{array}$ & $\begin{array}{l}\text { Miyagi } \\
2017^{29}\end{array}$ \\
\hline $\begin{array}{l}\text { Pain } \\
\text { behavior }\end{array}$ & $\begin{array}{l}\text { Surgicallyinduced } \\
\text { murine OA } \\
\text { model }\end{array}$ & $\begin{array}{l}\text { CuMVttNGF } \\
\text { vaccine }\end{array}$ & & $\begin{array}{l}\text { NGF vaccine strategy alleviated } \\
\text { spontaneous pain behavior in surgically } \\
\text { induced murine OA. Adverse effects were } \\
\text { not evaluated }\end{array}$ & $\begin{array}{l}\text { von Loga } \\
2018^{30}\end{array}$ \\
\hline
\end{tabular}

Abbreviations: NGF, nerve growth factor; DMM, destabilization of the medial meniscus; TrkA, tropomyosin receptor kinase A receptor; s.c., subcutaneous; MIA, monoiodoacetate; i.a., intra-articular; mAb, monoclonal antibody; OA, osteoarthritis; i.v., intravenous; PKC $\delta$, protein kinase $C \delta$; $M N X$, medial meniscal tear; o.g., oral gavage; i.p., intra-peritoneal; CGRP, calcitonin gene-related peptide; DRG, dorsal root ganglia.

evaluation of the effects of NGF blockade in pain and joint assessment were obtained by performing experiments on rat meniscal surgery models. Specifically, Nwosu et al reported that NGF blockade, obtained by inhibiting TrkA (AR786), reduced pain behavior in two rat models of $\mathrm{OA}^{25}$ LaBranche et $\mathrm{al}^{26}$ showed that tanezumab influenced weight-bearing and subsequent cartilage damage in the rat medial meniscal tear (MMT) model. Specifically, the authors demonstrated that treatment with tanezumab (at any dose) reduced gait imbalances induced by meniscal injury in the treated rat, but increased cartilage damage and subchondral bone sclerosis compared to controls. $\mathrm{Xu}$ et $\mathrm{al}^{27}$ demonstrated that anti-NGF mAb treatment (mainly in the early stages of the disorder) attenuated $\mathrm{OA}$ but increased cartilage damage in a rat model resembling the key clinical features of OA compared to controls. Nevertheless, these studies confirmed the analgesic role of anti-NGF mAb in the treatment of OA. Majuta et al demonstrated that anti-NGF improved limb use in a rodent model, by controlling pain after joint/orthopedic surgery. ${ }^{28}$ Miyagi et al demonstrated that an injection of anti-NGF antibody into the knee joint provoked an impairment of gait and dysregulation of calcitonin gene-related peptide (CGRP) in dorsal root ganglion (DRG) neurons in a knee OA pain mouse model. ${ }^{29}$
Promising results were obtained by von Loga et al, who demonstrated the therapeutic efficacy of a novel NGF vaccine (CuMVttNGF) in the alleviation of spontaneous pain behavior in surgically induced murine OA. ${ }^{30}$

Altogether, these studies support the idea that the blockade of NGF signaling is effective in treating chronic pain, especially in OA.

\section{Effects of Anti-NGF mAbs on Neuropathic and Cancer Pain: An Update on Preclinical Studies}

NGF plays important roles in nociception and in the maintenance, development, and injury of the sensory nervous system, which are directly involved in cancer pain manifestations. ${ }^{31}$ Based on these features, numerous preclinical studies have been conducted using anti-NGF mAbs therapy to manage cancer and neuropathic pain. ${ }^{17,32-42}$ Dai et al demonstrated that NGF inhibition mitigated chronic constriction injury (CCI)-induced neuropathic pain through the inhibition of downstream p65 and mitogen-activated protein kinase (MAPK). ${ }^{32}$ da Silva et al demonstrated that anti-NGF treatment reduced chronic neuropathic pain by changing peripheral mediators and brain activity in rats with CCI. ${ }^{14}$ Similarly, Dos Reis, in a rat model of trigeminal neuropathic pain, demonstrated that local treatment with anti-NGF attenuated heat hyperalgesia. ${ }^{33}$ With regard to 
cancer-related pain, a few preclinical studies have been conducted using anti-NGF mAb as a potential therapeutic choice. The first report was published by Sevcik et al. ${ }^{34}$ The authors demonstrated that an innovative NGF sequestering antibody was able to relieve cancer pain-related behaviors in a mouse model of bone cancer compared to conventional treatment with morphine. Similarly, Halvorson et al, in a prostate mouse model of bone cancer pain, demonstrated that anti-NGF treatment effectively suppressed alterations in functional connectivity after cancerinduced bone pain in mice. ${ }^{35}$ Later, Mantyh et al, using a mouse model of bone cancer pain, demonstrated that the analgesia obtained with administration of anti-NGF mAb stopped the development of severe cancer pain. ${ }^{36} \mathrm{~A}$ report by Ye et al highlighted the associations between pain, proliferation, and cachexia in oral cancer. ${ }^{37}$ Similarly, JimenezAndrade et al demonstrated that treatment with anti-NGF therapy in the early and later stages of the disease reduced cancer pain. ${ }^{38}$ Subsequently, Kumar et al published a review on the role of NGF/TrkA signaling in the treatment of chronic pain. ${ }^{17}$ Sainoh et al demonstrated that treatment with anti-NGF antibodies could be considered a valuable tool for the treatment of neuropathic cancer pain by lowering mechanical allodynia and upregulating the expression of pain markers. $^{39}$

Guedon et al conducted a study on the effects of antiNGF mAb or anti- purinergic receptor (P2X3) on skeletal pain-related behaviors in a murine model of cancerinduced bone pain (CIBP). Their data showed that, differently from anti-P2X3, which only attenuated the hypersensitivity of the skin, anti-NGF mAbs also mitigated skeletal pain-associated behaviors. ${ }^{40}$ In 2019, Buehlmann et al demonstrated that anti-NGF mAb treatment can prevent pain-induced adaptations in brain functional networks after persistent nociceptive input from cancer-induced bone pain. ${ }^{41}$ These findings suggest that anti-NGF therapy could be used successfully to treat neuropathic cancer pain.

\section{Clinical Trials: Safety and Efficacy of Anti-NGF mAbs in Chronic Pain Treatment}

Several mAbs that bind to NGF (ie tanezumab, fulranumab, and fasinumab) have been used in clinical studies for different chronic pain conditions, especially OA. (For a comprehensive review on this topic, see Wise et al. ${ }^{43}$ ) Specifically, phase I and phase II clinical trials have been conducted to test the efficacy of mAbs targeting NGF in pain attenuation in both knee and hip OA. ${ }^{43-71}$ As described by Wise et al, ${ }^{43}$ two primary endpoints have been used to study NGF inhibition in knee and hip OA in different studies: the Western Ontario and McMaster Universities Osteoarthritis Index (WOMAC) pain, which allows the meta-analyses of data; and function subscales, which are associated with the physician's global assessment (PGA). Overall, all of these studies demonstrated the efficacy of anti-NGF antibodies in pain alleviation and an improvement of the main patient outcomes compared to placebo (used as a control) for hip and knee OA. Despite these enthusiastic results, the meta-analyses conducted on data that emerged from these clinical trials found that treatment with mAbs targeting NGF increased the risk of neurological adverse effects (ie paresthesia, hypoesthesia, and peripheral neuropathy). However, no differences in serious adverse effects were detected after treatment with anti-NGF antibody compared to NSAID or placebo treatments, thus indicating the safety of the treatments used in these studies. To date, the clinical trials conducted on this topic have reported that NGF inhibitors attenuated joint pain and improved function compared with NSAIDs for a duration of up to 8 weeks. Specifically, the clinical efficacy of tanezumab started from week 4 after initiation of treatment and persisted for another 8 weeks thereafter. As discussed by Wise et $\mathrm{al}^{43}$ whereas anti-NGF mAbs produced significant pain relief and functional improvement in patients with knee and/or hip OA, clinical trials and meta-analyses conducted with tanezumab on nonspecific low back pain (LBP) gave mixed and confusing findings, but showed that LBP was less responsive to antiNGF agents than OA, even when tanezumab was used at higher doses. In particular, the meta-analysis conducted by Sanga et al, on the efficacy of anti-NGF mAbs (tanezumab, fulranumab, and fasinumab) in the treatment of CLBP, showed a slight improvement of pain and functions and an increase in neurological adverse effects compared to placebo. ${ }^{54}$ Finally, no conclusive evidence on the effectiveness of anti-NGF mAbs in chronic visceral or neuropathic pain has been presented. ${ }^{54}$

\section{Adverse Effects of Anti-NGF mAb Therapy for OA: An Update on the Clinical Trials}

Clinical trials and meta-analyses conducted on the use of anti-NGF $\mathrm{mAbs}$ in the treatment of OA (mainly 
tanezumab) reported some unforeseen side effects, particularly rapidly progressive osteoarthritis (RPOA) of both the knee and hip joints. Brown et al, ${ }^{44}$ in a randomized, double-blind, placebo-controlled phase III trial, showed that tanezumab $(2.5,5$, or $10 \mathrm{mg}$, i.v. $)$ alleviated osteoarthritic knee pain. However, an increase in neurological adverse effects was detected in the tanezumab compared to the placebo group, while no RPOA was detected. In a phase III placebo- and oxycodone-controlled study of tanezumab in adults with OA pain of the hip or knee, Spierings et $\mathrm{al}^{45}$ demonstrated the major efficacy of tanezumab in pain alleviation and the highest number of adverse effects in the oxycodone group. Similarly, Balanescu et $\mathrm{al}^{46}{ }^{46}$ in a phase III randomized clinical trial of tanezumab with diclofenac versus placebo in patients with OA pain of the hip or knee, showed a major efficacy of tanezumab on all primary outcomes. Total joint replacement (TJR) was frequently observed in the tanezumab group. Similar adverse events were observed in all groups, and one case of RPOA was confirmed by adjudication. Ekman et $\mathrm{al}^{47}$ tested the efficacy and safety of tanezumab ( 5 or $10 \mathrm{mg}$ ) for the treatment of OA of the knee or hip versus placebo or naproxen. They reported that tanezumab ameliorated the pain and PGA (at the dose of $5 \mathrm{mg}$ ) and function (at both doses) more than naproxen. No differences in side effects were detected in any treatment group, and one TJR was reported in the tanezumab group. Later, Schnitzer et $\mathrm{al}^{48}$ demonstrated that tanezumab improved pain and function in patients with OA more than NSAIDs and placebo. Regarding side effects, paresthesia and hypoesthesia were greater in patients with tanezumab than in patients treated with placebo and NSAIDs. Moreover, RPOA was observed mainly in patients treated with tanezumab alone. A clinical trial conducted by Birbara et $\mathrm{al}^{49}$ demonstrated the efficacy and safety of tanezumab in patients with knee or hip OA. A few cases of RPOA and TJRs were observed. Similarly, in two different clinical trials, Schnitzer et $\mathrm{al}^{50,51}$ showed that tanezumab improved all outcomes of patients with knee or hip OA. With regard to adverse effects, TJRs and RPOA were more evident in the tanezumab than in the placebo group, in a dose-dependent manner. Neurological adverse effects were also detected. Berenbaum et $a{ }^{52}$ in a randomized phase III study, demonstrated the efficacy and safety of tanezumab (2.5 or $5 \mathrm{mg}$ ) for OA of the hip or knee. RPOA occurred more frequently with a higher dose of tanezumab $(5 \mathrm{mg})$. TJRs were similarly distributed across all three groups. Hypoesthesia and paresthesia were also detected in both tanezumab groups.

A few trials have been conducted with other mABs. Mayorga et $\mathrm{al}^{53}$ conducted a randomized clinical controlled trial to test the efficacy and safety of fulranumab as monotherapy in patients with chronic knee pain of primary OA versus placebo and oxycodone treatment. Their data showed that the fulranumab group had better outcomes compared to the oxycodone group, but not to the placebo group. Neurological adverse events were higher in the fulranumab group than in the placebo group, but similar to the oxycodone group. More cases of TJRs were detected in the fulranumab group. Subsequently, Sanga et $\mathrm{al}^{54}$ demonstrated that long-term treatment with fulranumab was generally well tolerated and efficacious in patients with knee or hip OA.

Neurological adverse events and RPOA were more common in the fulranumab than in the placebo group. Dakin et $\mathrm{al}^{55}$ demonstrated that fasinumab provided improvements in OA pain and function, compared to placebo groups. Arthropathies, TRJs, and RPOA were more often observed in the fasinumab group. From these studies, it emerged that RPOA was associated with higher doses of anti-NGF antibodies used alone or with NSAIDs, although the underlying molecular mechanism is currently unknown. As reported by Wise et $\mathrm{al}^{43}$ an adjudication was performed by independent committees of experts to understand the risks associated with the use of anti-NGF mAbs. ${ }^{56,57}$ The clinical trial development programs subsequently resumed using lower doses of anti-NGF mAbs (2.5 and $5 \mathrm{mg}$ for tanezumab) in patients with painful knee or hip OA. ${ }^{12,58-71}$ Altogether, these studies indicate that anti-NGF mAbs represent a valuable biological therapy for OA pain, but some patients treated with the antibodies develop RPOA and neurological disorders. Unfortunately, the underlying molecular mechanisms have not been completely elucidated. It is possible that the inhibition of NGF signaling, via TrkA and $\mathrm{p} 75$ receptors on nociceptors, could compromise the loading signals of the joints, thus enhancing their degeneration.

\section{Conclusions and Future Perspectives}

Accumulating pieces of evidence have demonstrated that anti-NGF mAb therapy (ie fasinumab and tanezumab) ameliorates different chronic pain conditions, especially 
OA, CLBP, and neuropathic pain. Moreover, the analgesic efficacy of these anti-NGF antibodies is potentiated by the reduction of adverse effects associated with conventional pharmacological pain therapies (NSAIDs and opioids). ${ }^{72,73}$ Thus, anti-NGF mAb therapy could represent an alternative non-opioid therapeutic choice for pain management. Further studies are needed to understand the levels of analgesic effect, duration, immunogenicity, and potential adverse events of anti-NGF mAbs. Wtih regard to adverse events, in patients with large joint OA and treated with anti-NGF antibodies, RPOA and joint fractures have been reported. Thus, to ensure the safety of anti-NGF mAb treatment in these patients and others with chronic pain syndromes, it is necessary to set up new clinical studies focused on the identification of risk factors of patients with OA who manifest RPOA.

\section{Disclosure}

Sabrina Bimonte and Marco Cascella are co-first authors for this study. The authors report no conflicts of interest in this work.

\section{References}

1. Huang EJ, Reichardt LF. Neurotrophins: roles in neuronal development and function. Annu Rev Neurosci. 2001;24(1):677-736 doi:10.1146/annurev.neuro.24.1.677

2. Aloe L, Montalcini Leva R. The discovery of nerve growth factor and modern neurobiology. Trends Cell Biol. 2004;14(7):395-399. doi:10.1016/j.tcb.2004.05.011

3. Lewin GR, Ritter AM, Mendell LM. Nerve growth factor-induced hyperalgesia in the neonatal and adult rat. J Neurosci. 1993;13 (5):2136-2148. doi:10.1523/JNEUROSCI.13-05-02136.1993

4. Mizumura K, Murase S. Role of nerve growth factor in pain. Handb Exp Pharmacol. 2015;227:57-77.

5. Mantyh PW, Koltzenburg M, Mendell LM, Tive L, Shelton DL. Antagonism of nerve growth factor-TrkA signaling and the relief of pain. Anesthesiology. 2011;115(1):189-204. doi:10.1097/ ALN.0b013e31821b1ac5

6. Lindsay RM, Harmar AJ. Nerve growth factor regulates expression of neuropeptide genes in adult sensory neurons. Nature. 1989;337 (6205):362-364. doi:10.1038/337362a0

7. Julius D, Basbaum AI. Molecular mechanisms of nociception. Nature. 2001;413(6852):203-210. doi:10.1038/35093019

8. Hefti FF, Rosenthal A, Walicke PA, et al. Novel class of pain drugs based on antagonism of NGF. Trends Pharmacol Sci. 2006;27 (2):85-91. doi:10.1016/j.tips.2005.12.001

9. Watson JJ, Allen SJ, Dawbarn D. Targeting nerve growth factor in pain: what is the therapeutic potential? Bio Drugs. 2008;22 (6):349-359.

10. Miller RE, Block JA, Malfait AM. Nerve growth factor blockade for the management of osteoarthritis pain: what can we learn from clinical trials and preclinical models? Curr Opin Rheumatol. 2017;29(1):110-118. doi:10.1097/BOR.0000000000000354

11. Yeh JF, Akinci A, Al Shaker M, et al. Monoclonal antibodies for chronic pain: a practical review of mechanisms and clinical applications. Mol Pain. 2017;13:1744806917740233. doi:10.1177/ 1744806917740233
12. Lane NE, Schnitzer TJ, Birbara CA, et al. Tanezumab for the treatment of pain from osteoarthritis of the knee. N Engl J Med. 2010;363 (16):1521-1531. doi:10.1056/NEJMoa0901510

13. Enomoto M, Mantyh PW, Murrell J, Innes JF, Lascelles BDX. Antinerve growth factor monoclonal antibodies for the control of pain in dogs and cats. Vet Rec. 2019;184(1):23. doi:10.1136/vr.104590

14. da Silva JT, Evangelista BG, Venega RAG, Seminowicz DA, Chacur M. Anti-NGF treatment can reduce chronic neuropathic pain by changing peripheral mediators and brain activity in rats. Behav Pharmacol. 2019;30(1):79-88. doi:10.1097/ FBP.0000000000000422

15. Sabsovich I, Wei T, Guo TZ, et al. Effect of anti-NGF antibodies in a rat tibia fracture model of complex regional pain syndrome type I. Pain. 2008;138(1):47-60. doi:10.1016/j.pain.2007.11.004

16. Khan N, Smith MT. Neurotrophins and neuropathic pain: role in pathobiology. Molecules. 2015;20(6):10657-10688. doi:10.3390/ molecules200610657

17. Kumar V, Mahal BA. NGF - the TrkA to successful pain treatment. $J$ Pain Res. 2012;5:279-287. doi:10.2147/JPR.S33408

18. Barker PA, Mantyh P, Arendt-Nielsen L, Viktrup L, Tive L. Nerve growth factor signaling and its contribution to pain. $J$ Pain Res. 2020;26(13):1223-1241. doi:10.2147/JPR.S247472

19. McNamee KE, Burleigh A, Gompels LL, et al. Treatment of murine osteoarthritis with TrkAd5 reveals a pivotal role for nerve growth factor in non-inflammatory joint pain. Pain. 2010;149(2):386-392. doi:10.1016/j.pain.2010.03.002

20. Flannery CR, Moran N, Blasioli D, et al. Efficacy of a novel, locally delivered TrkA inhibitor in preclinical models of OA and joint pain. Osteoarthritis Cartilage. 2015;23(Supplement 2):A26-81. doi:10.1016/j.joca.2015.02.100

21. Bryden LA, Nicholson JR, Doods H, Pekcec A. Deficits in spontaneous burrowing behavior in the rat bilateral monosodium iodoacetate model of osteoarthritis: an objective measure of pain-related behavior and analgesic efficacy. Osteoarthritis Cartilage. 2015;23 (9):1605-1612. doi:10.1016/j.joca.2015.05.001

22. Ishikawa G, Koya $Y$, Tanaka H, Nagakura Y. Long-term analgesic effect of a single dose of anti-NGF antibody on pain during motion without notable suppression of joint edema and lesion in a rat model of osteoarthritis. Osteoarthritis Cartilage. 2015;23(6):925-932. doi:10.1016/j.joca.2015.02.002

23. Lascelles BD, Knazovicky D, Case B, et al. A canine-specific anti-nerve growth factor antibody alleviates pain and improves mobility and function in dogs with degenerative joint disease-associated pain. BMC Vet Res. 2015;30(11):101. doi:10.1186/s12917-015-0413-x

24. Kc R, Li X, Kroin JS, et al. PKC $\delta$ null mutations in a mouse model of osteoarthritis alter osteoarthritic pain independently of joint pathology by augmenting NGF/TrkA-induced axonal outgrowth. Ann Rheum Dis. 2016;75(12):2133-2141. doi:10.1136/annrheumdis2015-208444

25. Nwosu LN, Mapp PI, Chapman V, Walsh DA. Blocking the tropomyosin receptor kinase A (TrkA) receptor inhibits pain behaviour in two rat models of osteoarthritis. Ann Rheum Dis. 2016;75 (6):1246-1254. doi:10.1136/annrheumdis-2014-207203

26. LaBranche TP, Bendele AM, Omura BC, et al. Nerve growth factor inhibition with tanezumab influences weight-bearing and subsequent cartilage damage in the rat medial meniscal tear model. Ann Rheum Dis. 2017;76(1):295-302. doi:10.1136/annrheumdis-2015-208913

27. Xu L, Nwosu LN, Burston JJ, et al. The anti-NGF antibody muMab 911 both prevents and reverses pain behaviour and subchondral osteoclast numbers in a rat model of osteoarthritis pain. Osteoarthritis Cartilage. 2016;24(9):1587-1595. doi:10.1016/j. joca.2016.05.015

28. Majuta LA, Guedon JG, Mitchell SAT, Ossipov MH, Mantyh PW. Anti-nerve growth factor therapy increases spontaneous day/night activity in mice with orthopedic surgery-induced pain. Pain. 2017;158(4):605-617. doi:10.1097/j.pain.0000000000000799 
29. Miyagi M, Ishikawa T, Kamoda $H$, et al. Efficacy of nerve growth factor antibody in a knee osteoarthritis pain model in mice. $B M C$ Musculoskelet Disord. 2017;18(1):428. doi:10.1186/s12891-0171792-x

30. von Loga IS, El-Turabi A, Jostins L, et al. Active immunisation targeting nerve growth factor attenuates chronic pain behaviour in murine osteoarthritis. Ann Rheum Dis. 2019;78(5):672-675. doi:10.1136/annrheumdis-2018-214489

31. Johnson EM Jr, Rich KM, Yip HK. The role of NGF in sensory neurons in vivo. Trends Neurosci. 1986;9:33-37. doi:10.1016/01662236(86)90012-3

32. Dai WL, Yan B, Bao YN, Fan JF, Liu JH. Suppression of peripheral NGF attenuates neuropathic pain induced by chronic constriction injury through the TAK1-MAPK/NF- $\mathrm{KB}$ signaling pathways. Cell Commun Signal. 2020;18(1):66. doi:10.1186/s12964-020-00556-3

33. Dos Reis RC, Kopruszinski CM, Nones CF, Chichorro JG. Nerve growth factor induces facial heat hyperalgesia and plays a role in trigeminal neuropathic pain in rats. Behav Pharmacol. 2016;27 (6):528-535. doi:10.1097/FBP.0000000000000246

34. Sevcik MA, Ghilardi JR, Peters CM, et al. Anti-NGF therapy profoundly reduces bone cancer pain and the accompanying increase in markers of peripheral and central sensitization. Pain. 2005;115(12):128-141. doi:10.1016/j.pain.2005.02.022

35. Halvorson KG, Kubota K, Sevcik MA, et al. A blocking antibody to nerve growth factor attenuates skeletal pain induced by prostate tumor cells growing in bone. Cancer Res. 2005;65(20):9426-9435. doi:10.1158/0008-5472.CAN-05-0826

36. Mantyh WG, Jimenez-Andrade JM, Stake JI, et al. Blockade of nerve sprouting and neuroma formation markedly attenuates the development of late stage cancer pain. Neuroscience. 2010;171(2):588-598. doi:10.1016/j.neuroscience.2010.08.056

37. Ye Y, Dang D, Zhang J, et al. Nerve growth factor links oral cancer progression, pain, and cachexia. Mol Cancer Ther. 2011;10 (9):1667-1676. doi:10.1158/1535-7163.MCT-11-0123

38. Jimenez-Andrade JM, Ghilardi JR, Castañeda-Corral G, Kuskowski MA, Mantyh PW. Preventive or late administration of anti-NGF therapy attenuates tumor-induced nerve sprouting, neuroma formation, and cancer pain. Pain. 2011;152(11):2564-2574. doi:10.1016/j.pain.2011.07.020

39. Sainoh T, Sakuma Y, Miyagi M, et al. Efficacy of anti-nerve growth factor therapy for discogenic neck pain in rats. Spine (Phila $\mathrm{Pa}$ 1976). 2014;39(13):E757-62. doi:10.1097/BRS.0000000000000340

40. Guedon JG, Longo G, Majuta LA, Thomspon ML, Fealk MN, Mantyh PW. Dissociation between the relief of skeletal pain behaviors and skin hypersensitivity in a model of bone cancer pain. Pain. 2016;157(6):1239-1247. doi:10.1097/j.pain.0000000000000514

41. Buehlmann D, Ielacqua GD, Xandry J, Rudin M. Prospective administration of anti-nerve growth factor treatment effectively suppresses functional connectivity alterations after cancer-induced bone pain in mice. Pain. 2019;160(1):151-159. doi:10.1097/j. pain.0000000000001388

42. Miyagi M, Ishikawa $\mathrm{T}$, Kamoda $\mathrm{H}$, et al. The efficacy of nerve growth factor antibody in a mouse model of neuropathic cancer pain. Exp Anim. 2016;65(4):337-343. doi:10.1538/expanim.16-0014

43. Wise BL, Seidel MF, Lane NE. The evolution of nerve growth factor inhibition in clinical medicine. Nat Rev Rheumatol. 2021;17 (1):34-46. doi:10.1038/s41584-020-00528-4

44. Brown MT, Murphy FT, Radin DM, Davignon I, Smith MD, West CR. Tanezumab reduces osteoarthritic knee pain: results of a randomized, double-blind, placebo-controlled phase III trial. J Pain. 2012;13(8):790-798. doi:10.1016/j.jpain.2012.05.006

45. Spierings ELH, Fidelholtz J, Wolfram G, Smith MD, Brown MT, West CR. A phase III placebo- and oxycodone-controlled study of tanezumab in adults with osteoarthritis pain of the hip or knee. Pain. 2013;154(9):1603-1612. doi:10.1016/j.pain.2013.04.035
46. Balanescu AR, Feist E, Wolfram G, et al. Efficacy and safety of tanezumab added on to diclofenac sustained release in patients with knee or hip osteoarthritis: a double-blind, placebo-controlled, parallel-group, multicentre phase III randomised clinical trial. Ann Rheum Dis. 2014;73(9):1665-1672. doi:10.1136/annrheumdis-2012203164

47. Ekman EF, Gimbel JS, Bello AE, et al. Efficacy and safety of intravenous tanezumab for the symptomatic treatment of osteoarthritis: 2 randomized controlled trials versus naproxen. $J$ Rheumatol. 2014;41(11):2249-2259. doi:10.3899/jrheum.131294

48. Schnitzer TJ, Ekman EF, Spierings ELH, et al. Efficacy and safety of tanezumab monotherapy or combined with non-steroidal anti-inflammatory drugs in the treatment of knee or hip osteoarthritis pain. Ann Rheum Dis. 2015;74(6):1202-1211. doi:10.1136/ annrheumdis-2013-204905

49. Birbara C, Dabezies EJ Jr, Burr AM, et al. Safety and efficacy of subcutaneous tanezumab in patients with knee or hip osteoarthritis. $J$ Pain Res. 2018;8(11):151-164. doi:10.2147/JPR.S135257

50. Schnitzer TJ, Easton R, Pang S, et al. Effect of tanezumab on joint pain, physical function, and patient global assessment of osteoarthritis among patients with osteoarthritis of the hip or knee: a randomized clinical trial. JAMA. 2019;322(1):37-48. doi:10.1001/ jama.2019.8044

51. Schnitzer TJ, Khan A, Bessette L, et al. Onset and maintenance of efficacy of subcutaneous tanezumab in patients with moderate to severe osteoarthritis of the knee or hip: a 16-Week Dose-Titration Study. Semin Arthritis Rheum. 2020;50(3):387-393. doi:10.1016/j. semarthrit.2020.03.004

52. Berenbaum F, Blanco FJ, Guermazi A, et al. Subcutaneous tanezumab for osteoarthritis of the hip or knee: efficacy and safety results from a 24-week randomised phase III study with a 24-week follow-up period. Ann Rheum Dis. 2020;79(6):800-810. doi:10.1136/annrheumdis-2019-216296

53. Mayorga AJ, Wang S, Kelly KM, Thipphawong J. Efficacy and safety of fulranumab as monotherapy in patients with moderate to severe, chronic knee pain of primary osteoarthritis: a randomised, placebo- and active-controlled trial. Int J Clin Pract. 2016;70 (6):493-505. doi:10.1111/ijcp.12807

54. Sanga P, Katz N, Polverejan E, et al. Long-term safety and efficacy of fulranumab in patients with moderate-to-severe osteoarthritis pain: a Phase II Randomized, Double-Blind, Placebo-Controlled Extension Study. Arthritis Rheumatol. 2017;69(4):763-773. doi:10.1002/ art.39943

55. Dakin P, DiMartino SJ, Gao H, et al. The efficacy, tolerability, and joint safety of fasinumab in osteoarthritis pain: a phase IIB/III double-blind, placebo-controlled, randomized clinical trial. Arthritis Rheumatol. 2019;71(11):1824-1834. doi:10.1002/ art.41012

56. Bannwarth B, Kostine M. Targeting nerve growth factor (NGF) for pain management: what does the future hold for NGF antagonists? Drugs. 2014;74(6):619-626. doi:10.1007/s40265-014-0208-6

57. Hochberg MC, Tive LA, Abramson SB, et al. When is osteonecrosis not osteonecrosis?: adjudication of reported serious adverse joint events in the tanezumab clinical development program. Arthritis Rheumatol. 2016;68(2):382-391. doi:10.1002/art.39492

58. Hochberg MC, Carrino J, Schnitzer T, et al. Subcutaneous tanezumab versus NSAID for the treatment of osteoarthritis: joint safety events in a randomized, double- blind, active- controlled, 80-week, phase- 3 study. Arthritis Rheumatol. 2019;71:2756.

59. US National Library of Medicine. ClinicalTrials.gov; 2019. Available from: https://clinicaltrials.gov/ct2/show/NCT02709486. Accessed June 11, 2021.

60. US National Library of Medicine. ClinicalTrials.gov; 2020. Available from: https://clinicaltrials.gov/ct2/show/NCT02528188. Accessed June 11, 2021. 
61. Rashad S, Hemingway A, Rainsford K, et al. Effect of non- steroidal anti-inflammatory drugs on the course of osteoarthritis. Lancet. 1989;2(8662):519-522. doi:10.1016/S0140-6736(89)90651-X

62. Chen MR, Dragoo JL. The effect of nonsteroidal anti- inflammatory drugs on tissue healing. Knee Surg Sports Traumatol Arthrosc. 2013;21(3):540-549. doi:10.1007/s00167-012-2095-2

63. Kivitz AJ, Gimbel JS, Bramson C, et al. Efficacy and safety of tanezumab versus naproxen in the treatment of chronic low back pain. Pain. 2013;154(7):1009-1021. doi:10.1016/j.pain.2013.03.006

64. Gimbel JS, Kivitz AJ, Bramson C, et al. Long-term safety and effectiveness of tanezumab as treatment for chronic low back pain. Pain. 2014;155(9):1793-1801.

65. Hochberg MC, Carrino J, Schnitzer T, et al. Verburg KM Subcutaneous tanezumab versus NSAID for the treatment of osteoarthritis: joint safety events in a randomized, double-blind, active-controlled, 80-week, phase-3 study [abstract]. Arthritis Rheumatol. 2019;71:2756.

66. US National Library of Medicine. ClinicalTrials.gov; 2019. Available from: https://clinicaltrials.gov/ct2/show/NCT02709486. Accessed June 11, 2021.

67. Garber K, Aloe L. Fate of novel painkiller mAbs hangs in balance. Nat Biotechnol. 2011;29(3):173-174. doi:10.1038/nbt0311-173
68. US National Library of Medicine. ClinicalTrials.gov; 2020. Available from: https://clinicaltrials.gov/ct2/show/NCT02528188. Accessed June 11, 2021.

69. Kivitz AJ, Gimbel JS, Bramson C, et al. Efficacy and safety of tanezumab versus naproxen in the treatment of chronic low back pain. Pain. 2013;154(7):1009-1021.

70. Leite VF, Buehler AM, El Abd O, et al. Anti-nerve growth factor in the treatment of low back pain and radiculopathy: a systematic review and a meta-analysis. Pain Physician. 2014;17(1):E45-E60.

71. Karsdal MA, Verburg KM, West CR, et al. Serological biomarker profiles of rapidly progressive osteoarthritis in tanezumab- treated patients. Osteoarthritis Cartilage. 2019;27(3):484-492. doi:10.1016/ j.joca.2018.12.001

72. Bimonte S, Cascella M, Schiavone V, Mehrabi-Kermani F, Cuomo A. The roles of epigallocatechin-3-gallate in the treatment of neuropathic pain: an update on preclinical in vivo studies and future perspectives. Drug Des Devel Ther. 2017;11:2737-2742. doi:10.2147/DDDT.S142475

73. Cuomo A, Bimonte S, Forte CA, Botti G, Cascella M. Multimodal approaches and tailored therapies for pain management: the trolley analgesic model. J Pain Res. 2019;19(12):711-714. doi:10.2147/JPR. S178910
Journal of Pain Research

\section{Publish your work in this journal}

The Journal of Pain Research is an international, peer reviewed, open access, online journal that welcomes laboratory and clinical findings in the fields of pain research and the prevention and management of pain. Original research, reviews, symposium reports, hypothesis formation and commentaries are all considered for publication. The manuscript
Dovepress

management system is completely online and includes a very quick and fair peer-review system, which is all easy to use. Visit http:// www.dovepress.com/testimonials.php to read real quotes from published authors. 